\title{
Complete Genome Sequencing and Infectious cDNA Clone Construction of Soybean Mosaic Virus Isolated from Shanxi
}

\author{
Defu Wang ${ }^{1 \dagger}$, Liyan $\mathrm{Cui}^{2 \dagger}$, Li Zhang ${ }^{2}$, Zhennan $\mathrm{Ma}^{1}$, and Yanbing Niu (i) ${ }^{1 *}$ \\ ${ }^{1}$ College of Life Sciences, Shanxi Agricultural University, Taigu 030801, China \\ ${ }^{2}$ College of Grassland Science, Shanxi Agricultural University, Taigu 030801, China \\ (Received on November 10, 2020; Revised on February 28, 2021; Accepted on March 1, 2021)
}

Soybean mosaic virus (SMV) is the predominant viral pathogen that affects the yield and quality of soybean. The natural host range for SMV is very narrow, and generally limited to Leguminosae. However, we found that SMV can naturally infect Pinellia ternata and Atractylodes macrocephala. In order to clarify the molecular mechanisms underlying the crossfamily infection of SMV, we used double-stranded RNA extraction, rapid amplification of cDNA ends polymerase chain reaction and Gibson assembly techniques to carry out SMV full-length genome amplification from susceptible soybeans and constructed an infectious cDNA clone for SMV. The genome of the SMV Shanxi isolate (SMV-SX) consists of 9,587 nt and encodes a polyprotein consisting of $3,067 \mathrm{aa}$. SMV-SX and SMV-XFQ008 had the highest nucleotide and amino acid sequence identities of $97.03 \%$ and $98.50 \%$, respectively. A phylogenetic tree indicated that SMV-SX and SMV-XFQ018 were clustered together, sharing the closest relationship. We then constructed a pSMV-SX infectious cDNA clone by Gibson assembly technology and used this clone to inoculate soybean and Ailanthus altissima; the symptoms of these hosts were similar to those caused by the virus isolated from natural

\footnotetext{
These authors contributed equally to this work.

*Corresponding author.

Phone, FAX) +86-0354-6287205

E-mail) niuyanbingbest@163.com

ORCID

Yanbing Niu

https://orcid.org/0000-0001-9618-1886

(c) This is an Open Access article distributed under the terms of the Creative Commons Attribution Non-Commercial License (http:// creativecommons.org/licenses/by-nc/4.0) which permits unrestricted noncommercial use, distribution, and reproduction in any medium, provided the original work is properly cited.
}

Articles can be freely viewed online at www.ppjonline.org. infected plant tissue. This method of construction not only makes up for the time-consuming and laborious defect of traditional methods used to construct infectious cDNA clones, but also avoids the toxicity of the Potyvirus special sequence to Escherichia coli, thus providing a useful cloning strategy for the construction of infectious cDNA clones for other viruses and laying down a foundation for the further investigation of SMV cross-family infection mechanisms.

Keywords : genome sequencing, Gibson assemblyinfectious clone, soybean mosaic virus

Handling Editor : Ho-Jong Ju

Soybean (Glycine max (L.) Merr) is an annual herbaceous plant of the Leguminosae soybean family and represents the world's main oil crop. Soybean is also rich in soluble fibers, saponins, proteins, fats, and other nutrients that are beneficial to human growth and development. However, viral diseases have become an increasingly serious threat to soybean, causing enormous losses in both yield and quality. According to previous researches, more than 110 plant viruses in the United States are known to infect soybeans; in China over 50 viruses have been reported (Cui et al., 2018; Zhi, 2005). Of those, SMV is the predominant virus known to infect soybean. The range of natural hosts for SMV is particularly narrow and is generally limited to Leguminosae (Zheng et al., 2000; Zhou and $\mathrm{Pu}, 1990)$. However, over recent years, researchers have found that SMV can naturally infect Pinelliae ternata (Rohozková and Navrátil, 2011; Shentu, 2006; Shi, 2007; Sun et al., 2008). In a previous report, we described the isolation of SMV from susceptible $P$. ternata (SMVSXBX), and phylogenetic tree showed that SMV-SXBX and SMV Pinellia isolates were clustered together, but 
far from SMV soybean isolates (Cui et al., 2018). In addition, we have also found that SMV can naturally infect Atractylodes macrocephala (Compositae) in China (data not published). However, the molecular mechanism of SMV cross-family infection is still unknown. As a technology, infectious cloning has been widely used in the study of pathogenicity of plant viruses. At present, we have successfully constructed the infectious cDNA clone of SMV-SXBX (Zhang et al., 2020), but it is not enough to clarify the molecular mechanisms underlying the crossfamily infection of SMV. Therefore, this study is dedicated to construction of the infectious cDNA clone of SMV soybean isolate (SMV-SX).

Infectious clones for plant viruses refer to DNA clones that have been constructed artificially using molecular biology techniques and have the same infectious activity as plant viruses under natural conditions. The essence of these infectious clones is that they represent a DNA gene bank that contains the complete genome information of the virus (Boyer and Haenni, 1994). Normally, full-length cDNA clones for plant viruses are constructed using reverse genetics technology and subsequently used to explore RNA viruses at the DNA level, thus overcoming operational difficulties at the RNA level. The first successfully constructed infectious clone of an RNA virus was brome mosaic virus (BMV) (Ahlquist et al., 1984). Since then an increasing number of RNA viruses have been used to construct infectious clones, including cucumber mosaic virus (CMV) (Rizzo and Palukaitis, 1990), tomato aspermy cucumovirus (TAV) (Shi et al., 1997), beet mild yellowing virus (BMYV) (Stephan and Maiss, 2006), tomato yellow leaf curl sardinia virus (TYLCSV) (Kondo and Fujita, 2012), ribgrass mosaic virus (RMV) (Zhu et al., 2006), potato virus M (PVM) (Flatken et al., 2008), and pepper mottle virus (PMV) (Lee et al., 2011). However, the construction of infectious clones for Potyviruses is particularly challenging due to the presence of special viral sequences that have a toxic effect on Escherichia coli (Chikh Ali et al., 2011; Johansen and Lund, 2008); consequently, only a few reports have described the construction of such clones. The successful generation of infectious clones for Potyviruses has now been described for tobacco vein mottling virus (TVMV) (Domier et al., 1989; Nicolas et al., 1997), zucchini yellow mosaic virus (ZYMV) (Gal-On et al., 1991; Lin et al., 2002), tobacco etch virus (TEV) (Bedoya and Daròs, 2010; Dolja et al., 1992), peanut stripe virus (PStV) (Flasinski et al., 1996), potato virus A (PVA) (Puurand et al., 1996; Rajamäki and Valkonen, 2009), papaya ringspot virus (PRSV) (Chiang and Yeh, 1997), potato virus Y (PVY) (Chikh Ali et al.,
2011; Jakab et al., 1997), turnip mosaic virus (TuMV) (Sánchez et al., 1998), johnsongrass mosaic virus (JGMV) (Kim et al., 2003), PMV (Lee et al., 2011), bean common mosaic virus (BCMV) (Naderpour and Johansen, 2011), and maize dwarf mosaic virus (MDMV) (Stewart et al., 2012). Although an infectious clone was successfully constructed for SMV in 1996 (Seo et al., 2009), the construction method was time-consuming and laborious.

In this study, we used Gibson assembly technology to rapidly construct an SMV-SX infectious clone in the form of a shuttle plasmid featuring both Escherichia coli and Agrobacterium recognition start sites. This method overcomes the limitations imposed by traditional construction methods that are time-consuming and laborintensive, while also avoiding the toxicity of SMV special sequences to $E$. coli. We expect our findings to provide a reference for the construction of infectious clones for other viruses, and lay a foundation for further research relating to mechanisms of virus infection.

\section{Materials and Methods}

Materials. Fresh leaves from soybean plants that showed mosaic symptoms were collected from Jinzhong in Shanxi province in China in July 2018 and stored in liquid nitrogen for subsequent testing.

Extraction of double-stranded RNA and amplification of the SMV-SX genome. Total double-stranded RNA (dsRNA) of symptomatic soybean was extracted according to the method described previously by Krajacić et al. (2007), Li et al. (2007), and Tzanetakis and Martin (2008). Next, we generated first-strand cDNAs from dsRNA via reverse transcription polymerase chain reaction (RT-PCR) with moloney murine leukemia virus reverse transcriptase (Promega, Madison, WI, USA) and an oligo $(\mathrm{dT})_{18}$ primer at $42^{\circ} \mathrm{C}$ for $1 \mathrm{~h}$ and $70^{\circ} \mathrm{C}$ for $15 \mathrm{~min}$. The complete viral genome was obtained through several RT-PCR amplifications and covering all gaps with virus-specific primers (Supplementary Table 1). The PCR conditions were set as described previously (Niu et al., 2018). We then performed rapid amplification of cDNA ends (RACE) PCR using a RACE kit (TaKaRa, Dalian, China) in accordance with the manufacturer's recommendations. The PCR products were purified using an agarose gel DNA Gel Extraction kit (OMEGA, Guangzhou, China) in accordance with the manufacturer's recommendations. The purified fragment was cloned directly into the pEASY-Blunt vector (TransGen, Beijing, China) and transformed into E. coli strain DH5 $\alpha$ for Sanger sequencing. 
Bioinformatics analysis of SMV-SX. The amplified sequences were spliced using SeqMan tool from the DNASTAR package (DNASTAR, Inc., Madison, WI, USA). Multiple sequence alignment was carried out for nucleotide and amino acid sequence using the optimal alignment tool in the DNAMAN software package (Lynnon, Biosoft, Canada). Phylogenetic tree performed by a maximum likelihood method with MEGA 7.1 software and ORF finder was used to predict the amino acid sequence encoded by nucleotides.

Construction of pSMV-SX via Gibson assembly. The full-length SMV-SX cDNA was divided into two overlapping amplified fragments using specific primers and ensuring that there was a 25-base-pair overlap (Table 1). A $35 \mathrm{~S}$ promoter and a CaMV polyA terminator were inserted into the multiple cloning sites of the binary pGreenII 0000 expression vector to generate pGreen-35S (Hellens et al., 2000). The pGreen-35S was amplified by primers with 25-33 bases that were homologous to the viral genome fragments. The PCR amplification reactions were performed with PrimeSTAR GXL DNA Polymerase (Takara). Amplicons of the expected sizes were purified with a DNA Gel Extraction kit (OMEGA). The viral genome fragments were then cloned into the linearized pGreen-35S vector by Gibson assembly (Tuo et al., 2017). The reaction was performed in a total volume of $10 \mu \mathrm{l}$, containing $150 \mathrm{ng}$ of each purified PCR fragment and $5 \mu 1$ of $2 \times$ Gibson Mix (NEB). The reaction mix was incubated at $50^{\circ} \mathrm{C}$ for $1 \mathrm{~h}$, and then placed on ice prior to transformation into the Rhizobium radiobacter (synonym Agrobacterium tumefaciens).
Transformation of Agrobacterium tumefaciens and transfection. A reaction mix $(5 \mu \mathrm{l})$ was transformed into $100 \mu 1$ of Agrobacterium tumefaciens strain GV3101 (Weidi Biotech, Shanghai, China) competent cells (containing the pSoup helper plasmid) by electroporation according to a standard protocol. The transformants were then screened on Luria-Bertani (LB) medium containing 50 $\mathrm{mg} / \mathrm{l}$ of kanamycin and $50 \mathrm{mg} / \mathrm{l}$ of rifampicin for 3 days at $28^{\circ} \mathrm{C}$, and then screened by colony PCR using the primers shown in Supplementary Table 1. The plasmids (final $30 \mu \mathrm{l})$ were extracted from $80 \mathrm{ml}$ culture of the positive colonies for sequencing.

Agroinfiltration was performed as previously described (Sparkes et al., 2006; Yan et al., 2012). A positive single colony of agrobacterium was picked from each infectious clone in order to inoculate $10 \mathrm{ml}$ of LB medium supplemented with $50 \mathrm{mg} / 1$ of kanamycin and $50 \mathrm{mg} / 1$ of rifampicin. Bacteria were grown overnight at $28^{\circ} \mathrm{C}$ until they reached an $\mathrm{OD}_{600}$ of 1.0-1.5. The cultures were then pelleted and washed using infiltration buffer (10 mM MES pH 5.6, $10 \mathrm{mM} \mathrm{MgCl}_{2}$, and $100 \mu \mathrm{M}$ a cetosyringone). Then, cells were diluted with infiltration buffer to a final $\mathrm{OD}_{600}$ of 0.6-0.8 and incubated for $3 \mathrm{~h}$ at room temperature in the dark prior to the agroinfiltration of soybean and $A$. altissima plants using $1 \mathrm{ml}$ - syringes without a needle.

The plasmid inoculation approach was performed as previously described (Kang et al., 2016; Seo et al., 2009). Plasmid DNA of pSMV-SX was prepared using the Plasmid Maxi Kit (Qiagen, Shanghai, China). Approximately $50 \mu \mathrm{g}$ plasmid DNA was diluted in $50 \mathrm{mM}$ potassium phosphate, $\mathrm{pH} 7.5$, to a total volume of $100 \mu \mathrm{l}$ and inoculated onto two leaves per plant by direct rub-

Table 1. Primer pairs for creating SMV-SX infectious cDNA clones

\begin{tabular}{|c|c|c|}
\hline Primer name & Primer sequence $\left(5^{\prime}-3^{\prime}\right)$ & Description \\
\hline pGr35S-smvF & $\begin{array}{l}\text { CCTAAAAAAAAAAAAAAAAAAAAAAAAAAAA } \\
\underline{\text { AAAAAAAAAAAAAAAAAAAAAAAAAAAA }} \\
\underline{\text { TCGGTACGCTGAAATCACCAGTCTC }}\end{array}$ & For vector of SMV \\
\hline pGr35S-R & ССТСТССАААТGAАATGAАСТTССТ & \\
\hline $\mathrm{SMV}-\mathrm{F}_{1}$ & $\begin{array}{l}\text { AGGAAGTTCATTTCATTTGGAGAGG } \\
\text { AAATTAAAACTAGTTATAAA GACAGCAAACAAATTAAAC }\end{array}$ & For SMV fragment 1 \\
\hline SMV-R ${ }_{3716}$ & AGAGACGCTGGAAGACTCCTTATTTG & \\
\hline $\mathrm{SMV}-\mathrm{F}_{3697}$ & AGGAGTCTTCCAGCGTCTCTTTTGA & For SMV fragment 2 \\
\hline SMV-R & $\begin{array}{l}\text { CGATTTTTTTTTTTTTTTTTTTTTTTTTTTT } \\
\frac{\text { TTTTTTTTTTTTTTTTTTTTTTTTTTT }}{\underline{\text { AGGACAACAAACATTGCCGTA }}}\end{array}$ & \\
\hline SMV-CP-F & TTACAATCAGGCAAGGAGAAGGAA & For RT-PCR detection \\
\hline SMV-CP-R & GGGTCAAAACCACACTAAACAAAAG & \\
\hline
\end{tabular}

The sequence marked with a horizontal line represents a homologous sequence.

SMV, soybean mosaic virus; SMV-SX, SMV Shanxi isolate; RT-PCR, reverse transcription polymerase chain reaction. 

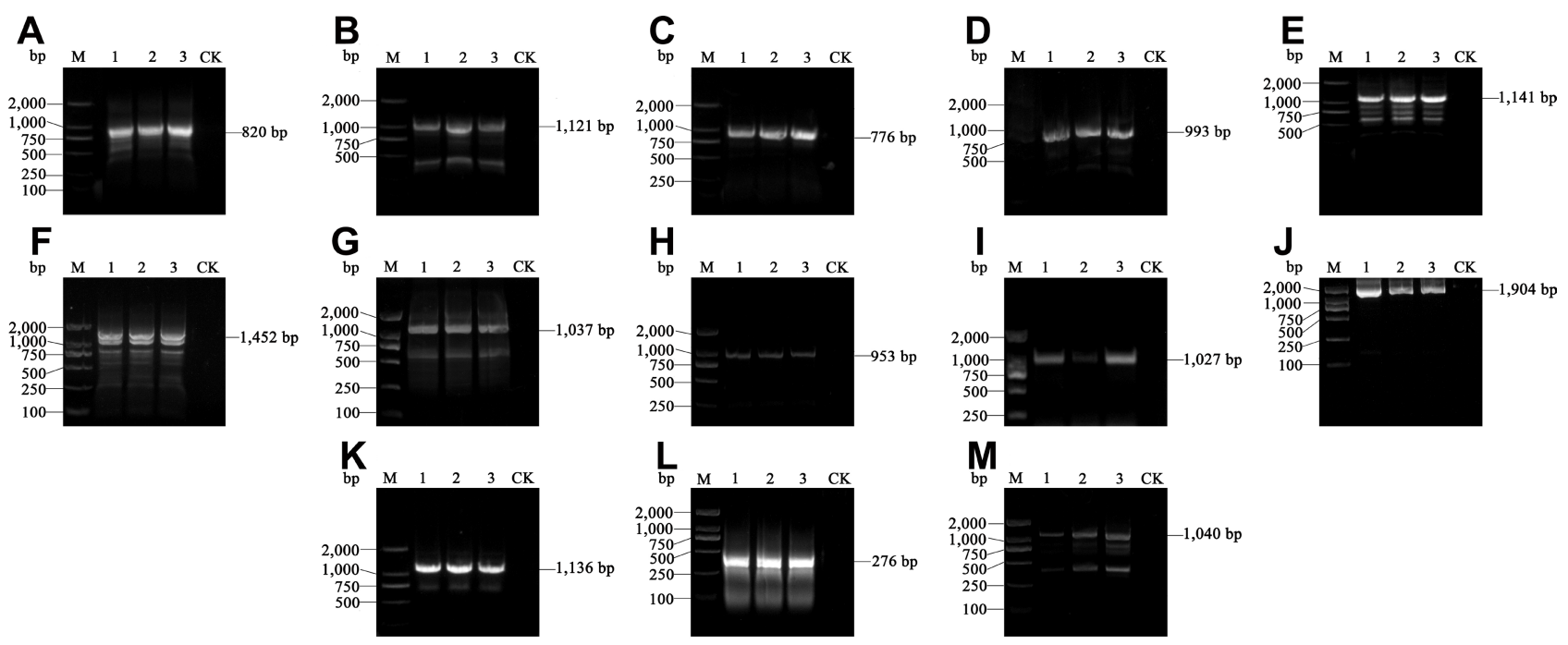

Fig. 1. Image of agarose gel electrophoresis of reverse transcription polymerase chain reaction products from the SMV-SX genome. (A-K) Primer set SMV-F1-11 + SMV-R1-11: lanes 1-3, infected plants; CK, healthy plants; M, DL 2000TM DNA marker. (L) 5' RACE: lanes $1-3$, the $5^{\prime}$ proximal end length; CK, healthy plants; M, DL 2000TM DNA marker. (M) 3' RACE: lanes 1-3, the 3' proximal end length; CK, healthy plants; M, DL 2000TM DNA marker. SMV, soybean mosaic virus; SMV-SX, SMV Shanxi isolate.

inoculation with carborundum. All the inoculated plants were grown in a controlled environment with a $16 \mathrm{~h}$ light cycle at $28^{\circ} \mathrm{C}$ and then for $8 \mathrm{~h}$ in the dark at $25^{\circ} \mathrm{C}$. After 45 days inoculation, the symptoms of inoculated plant leaves were photographed and further detected by RT-PCR technique.

RT-PCR. Total RNA was extracted from the upper noninoculated leaves of the inoculated plants for RT-PCR using Tap DNA polymerase (TransGen) and a specific set of primers: SMV-CP-F and SMV-CP-R (Table 1). The PCR products were then transformed into $E$. coli $\mathrm{DH} 5 \alpha$ for sequencing.

\section{Results}

Structure characteristics of the SMV-SX genome. First, dsRNA was extracted from diseased soybean leaves and reverse transcribed into cDNA to act as a template. We then used 11 pairs of specific primers and 2 pairs of RACE primers to amplify the entire SMV-SX genome. A series of fragments were produced, all of the expected sizes 820 , 1,121, 776, 993, 1,141, 1,452, 1,037, 953, 1,027, 1,904, and 1,136 bp (Fig. 1). The SMV-SX genome consists of 9,587 $\mathrm{nt}$ and was determined by assembling the 13 amplified fragments using DNASTAR software.

The genomic organization of SMV-SX is typical for members of the Potyvirus genus and is consistent with that of other SMV sequences, with a large open reading frame (ORF) encoding a putative polyprotein of 3,067 amino acids. The ORF begins at nt position 133 and ends with a stop codon at position 9332-9335. The $5^{\prime}$ and $3^{\prime}$ untranslated regions consist of 132 and $252 \mathrm{nt}$, respectively. The polyprotein has nine putative cleavage sites and can be cleaved into ten mature proteins (P1, HC-Pro, P3, 6K1, CI, $6 \mathrm{~K} 2, \mathrm{VPg}, \mathrm{NIa}, \mathrm{NIb}$, and $\mathrm{CP}$ ). The cleavage site in the P1/

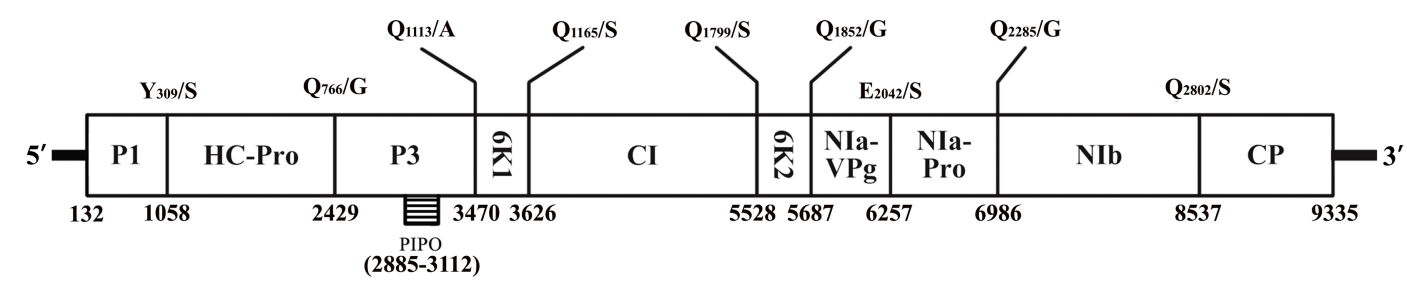

Fig. 2. Images showing the organization of the SMV-SX genome. Open reading frames are represented by boxes while the numbers under the boxes represent the nucleotide position. The uppercase letters above the boxes indicate predicted cleavage sites. SMV-SX, soybean mosaic virus Shanxi isolate. 
Table 2. A comparison of nucleotide and amino acid sequence homology between SMV-SX and other SMV isolates

\begin{tabular}{|c|c|c|c|c|c|}
\hline Isolate & $\begin{array}{c}\text { GenBank } \\
\text { accession no. }\end{array}$ & Host & Location & $\begin{array}{c}\text { Nucleotide sequence } \\
\text { identities }(\%)\end{array}$ & $\begin{array}{c}\text { Amino sequence } \\
\text { identities (\%) }\end{array}$ \\
\hline Aa15-M2 & AB100443 & Soybean & Japan & 92.97 & 96.84 \\
\hline CN18 & AJ619757 & Soybean & South Korea & 92.11 & 95.63 \\
\hline G7 & AY216010 & Soybean & USA & 92.57 & 96.54 \\
\hline G5 & AY294044 & Soybean & South Korea & 94.41 & 97.52 \\
\hline G7H & AY294045 & Soybean & South Korea & 94.85 & 97.78 \\
\hline $\mathrm{L}$ & EU871724 & Soybean & Canada & 95.31 & 97.91 \\
\hline WS200 & FJ548849 & Wild soybean & South Korea & 94.86 & 97.65 \\
\hline WS105 & FJ640958 & Wild soybean & South Korea & 92.92 & 96.77 \\
\hline WS117 & FJ640962 & Wild soybean & South Korea & 93.66 & 96.97 \\
\hline WS128 & FJ640963 & Wild soybean & South Korea & 95.00 & 97.65 \\
\hline WS155 & FJ640970 & Wild soybean & South Korea & 92.64 & 96.61 \\
\hline WS156 & FJ640971 & Wild soybean & South Korea & 92.89 & 96.80 \\
\hline WS160 & FJ640972 & Wild soybean & South Korea & 95.09 & 97.55 \\
\hline G1 & FJ640977 & Soybean & South Korea & 93.71 & 97.26 \\
\hline 413 & GU015011 & Soybean & USA & 93.65 & 97.39 \\
\hline $4547 / \mathrm{CHN} / 2004$ & HQ396725 & Soybean & China & 87.03 & 90.76 \\
\hline $\mathrm{SC} 3$ & JF833013 & Soybean & China & 93.42 & 96.90 \\
\hline Lo3 & KF135490 & Soybean & Iran & 94.82 & 97.95 \\
\hline Go11 & KF135491 & Soybean & Iran & 94.70 & 97.82 \\
\hline Ar33 & KF297335 & Soybean & Iran & 94.82 & 97.98 \\
\hline India & KM979229 & Soybean & India & 94.40 & 97.46 \\
\hline SC7-N & KP710868 & Soybean & China & 87.40 & 90.76 \\
\hline XFQ008 & KP710873 & Soybean & China & 97.03 & 98.50 \\
\hline XFQ010 & KP710874 & Soybean & China & 94.90 & 98.08 \\
\hline XFQ018 & KP710877 & Soybean & China & 93.19 & 97.16 \\
\hline JAAS-6 & KR024718 & Soybean & China & 88.10 & 89.50 \\
\hline HB-RS & KR065437 & Soybean & China & 87.68 & 90.51 \\
\hline China & KX096578 & Soybean & China & 93.15 & 97.49 \\
\hline SC001 & KX834320 & Soybean & China & 88.11 & 90.85 \\
\hline JSJJ001 & KX834321 & Soybean & China & 87.90 & 90.94 \\
\hline HLJBADS001 & KX834324 & Soybean & China & 94.73 & 96.58 \\
\hline HLJHLQF001 & KX834325 & Soybean & China & 92.49 & 96.94 \\
\hline CC2515 & KY986929 & Vigna angularis & South Korea & 95.30 & 97.72 \\
\hline $\mathrm{N}$ & NC_002634 & Soybean & USA & 95.18 & 97.72 \\
\hline Severe strain & AJ312439 & Soybean & China & 93.23 & 81.93 \\
\hline $\mathrm{HZ1}$ & AJ628750 & Pinellia ternata & China & 78.65 & 83.54 \\
\hline $\mathrm{NN}$ & KF982784 & Pinellia pedatisecta & China & 78.03 & 83.80 \\
\hline $\mathrm{Am}$ & КC845322 & Atractylodes macrocephala & China & 75.19 & 81.70 \\
\hline SC001 & KX834320 & Soybean & China & 88.11 & 90.85 \\
\hline G2 & S42280.1 & Soybean & USA & 94.92 & 97.03 \\
\hline SXBX & MT712111 & Pinellia ternata & China & 76.12 & 82.53 \\
\hline
\end{tabular}

SMV, soybean mosaic virus; SMV-SX, SMV Shanxi isolate.

HC-Pro dipeptide is predicted to be cleaved by the P1 serine proteinase, whereas the cleavage site in the HC-Pro/P3 is cleaved by the HC-Pro cysteine proteinase. In addition, the cleavage sites of the seven other dipeptides are cleaved by the NIa-Pro cysteine proteinase. The predicted cleavage sites are as follows: IQHY309/S (P1/HC-Pro), YRVG766/ G (HC-Pro/P3), VSAQ1113/A (P3/6K1), VKVQ1165/S (6K1/CI), VQLQ1799/S (CI/6K2), VSTQ1852/G (6K2/ 


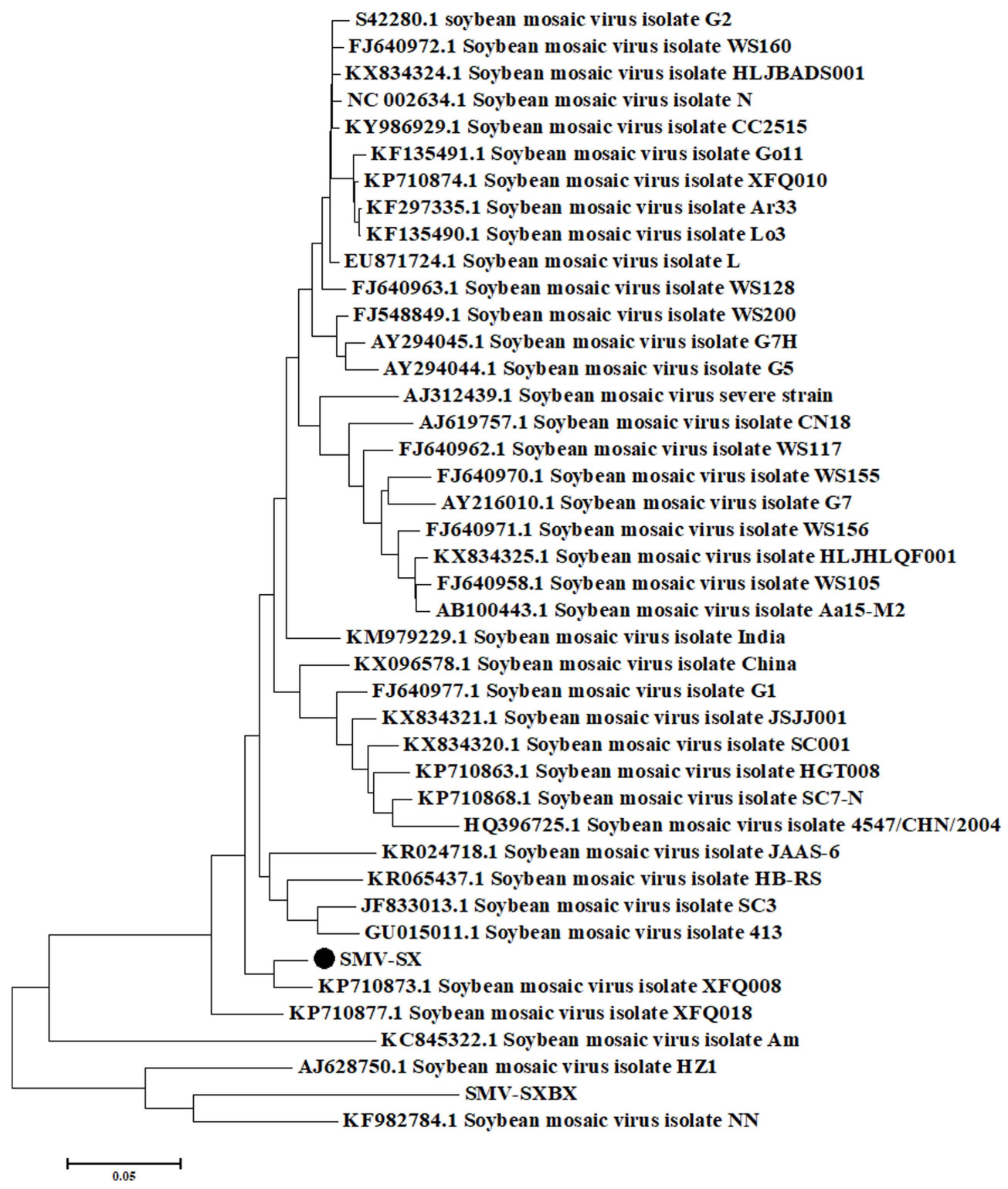

Fig. 3. Phylogenetic tree based on the nucleotide sequences of SMV-SX and other SMV isolates. Phylogenetic tree was constructed by the maximum likelihood method with 1,000 bootstrap replicates. SMV, soybean mosaic virus; SMV-SX, SMV Shanxi isolate.

NIa-VPg), VEME2042/S (NIa-VPg/NIaPro), VTVQ 2285/ G (NIa-Pro/NIb), and VSLQ2802/S (NIb/CP) (Fig. 2).

SMV-SX sequence similarity. The homology and similarity of SMV-SX with other SMV isolates were analyzed using DNAMAN software and showed that the nucleotide and amino acid identities were $75.19-97.03 \%$ and $81.70-$ $98.50 \%$, respectively (Table 2). SMV-SX had the highest identity to SMV-XFQ008 from China. The identities of the nucleotide and amino acid sequences were $97.03 \%$ and $98.50 \%$, respectively. Phylogenetic analysis also showed that the SMV-SX isolate clustered with SMV-XFQ008
(Fig. 3).

Construction of a pSMV-SX plasmid by Gibson assembly. Using the 3'-RACE reverse transcription product of the soybean dsRNA as a template, we used two large pairs of specific primers (SMV-F1/SMV-R3716 and SMV-F3697/ SMV-R1) (Table 1) to amplify fragments of 3,738 bp and $5,894 \mathrm{bp}$, respectively. Using the pGreen-35S plasmid as a template, and using specific primers (pGr35S-smvF/ pGr35S-R), we then obtained the target band of 3,233 bp by reverse PCR (Fig. 4A-C). Gibson assembly technology was then used to ligate the two SMV fragments into the 

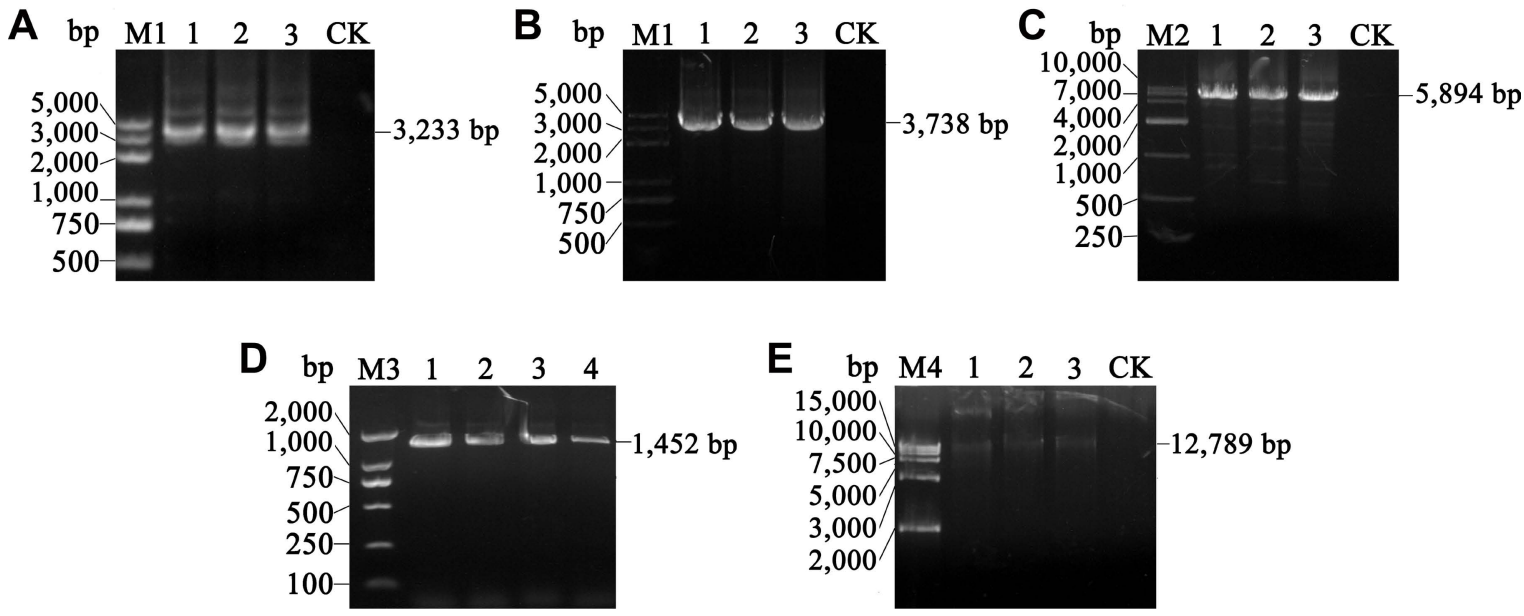

Fig. 4. Image of agarose gel electrophoresis of reverse transcription polymerase chain reaction products from SMV-SX infectious clones. (A) PCR product from pGr35S-smvF/pGr35S-R. (B) PCR product from SMV-F1/SMV-R3716. (C) PCR product from SMV-F3697/ SMV-R1. (D) PCR product from colony PCR using specific primers SMV-F6 and SMV-R6. (E) The recombination vector plasmid extraction result. M1, DL 5000 DNA marker; M2, DL 10000 DNA marker; M3, DL 2000 DNA marker; M4, DL 15000 DNA marker; lanes 1-3, infected plant; CK, healthy plant. SMV, soybean mosaic virus; SMV-SX, SMV Shanxi isolate.

linearized pGreen-35S vector. The recombination vector was subsequently electroporated into Agrobacterium GV3101 (pSoup) competent cells. Positive clones were then identified by colony PCR using specific primers SMV-F6 and SMV-R6 (Fig. 4D, Supplementary Table 1) and plasmid extraction (Fig. 4E).

Activity analysis of the infectious pSMV-SX clone. Agrobacterium infiltration and plasmid inoculation were used to inoculate soybean varieties (Kefeng No. 1 and 1138-2 at the 3-4 leaf stage) and A. altissima. After 45 days, the inoculated plants all showed symptoms of susceptibility (Fig. 5D-F). We then extracted RNA from the symptomatic leaves of all plants and used this as a template for RT-PCR using SMV-CP-F and SMV-CP-R primers, the electrophoresis and sequencing results showed that the constructed SMV-SX infectious clone had infectious activity (Fig. 5G-I).

\section{Discussion}

Plant viruses have caused a range of serious diseases in a wide variety of plants, thus causing global economic losses of up to 30 billion dollars annually (Sastry and Zitter, 2014). More than $90 \%$ of viral nucleic acids in plants are single-stranded RNA, and dsRNA is produced when replicated (Zhou and $\mathrm{Li}, 1995$ ). The principle that dsRNA can be specifically adsorbed by cellulose CF-11 at a certain concentration of alcohol can be used to identify plant viruses (Tian and Wang, 1995). dsRNA technology overcomes the limitations associated with the use of single-stranded RNA in traditional RT-PCR, is stable during extraction, and is not affected by polyphenols and polysaccharides. This technology is not only simple and convenient to operate, but can also detect known, unknown, and low concentration viruses. In addition, the combination of dsRNA and sequence-independent amplification technology can achieve the purpose of detecting multiple viruses simultaneously (Kou et al., 2017). Niu et al. (2003), Wang et al. (2016), and Yang et al. (2017), all used this technology to detect pear vein yellow virus (PVYV), youcai mosaic virus (YoMV), and malva vein clearing virus (MVCV).

Techniques to clone infectious plant viruses have been applied to many aspects of plant virus research. First, those techniques have been used to investigate the molecular biology of viruses; Galiakparov et al. (2003) used infectious cloning techniques to investigate the proteins encoded by the five ORFs of grapevine virus A (GVA). Second, those techniques have been used to investigate viral pathogenic factors; Chiang et al. (2007) used infectious cloning technology to show that three amino acids in the P1 and HC-Pro regions of PRSV are closely related to the pathogenicity of the virus. Third, this technology has been used to construct plant expression vectors (Chapman et al., 1992) and gene silencing vectors (Liu and Lomonossoff, 2002). Fourth, these techniques have been used to develop attenuated strains. By using reverse genetics to make site- 
A

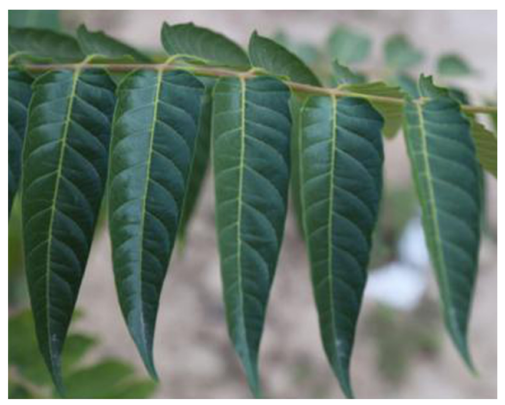

D

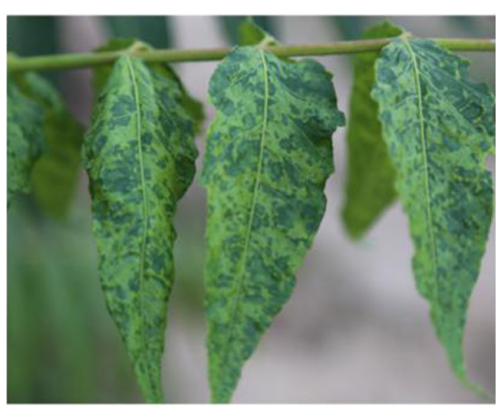

G

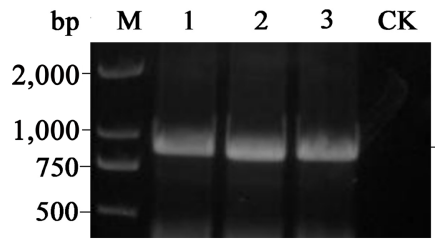

B

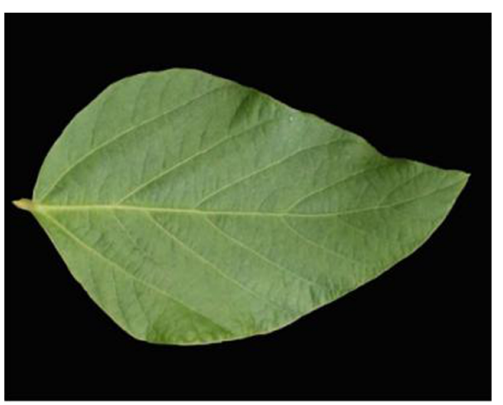

E

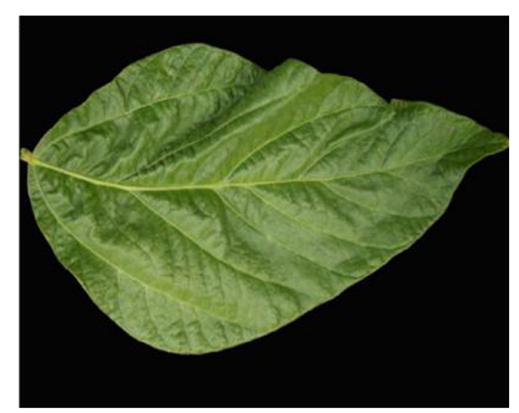

H

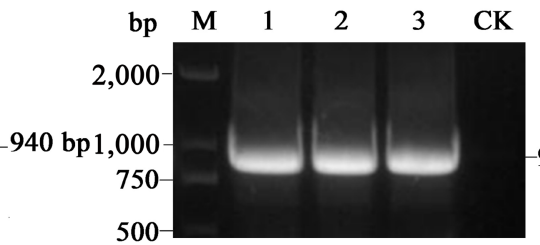

C

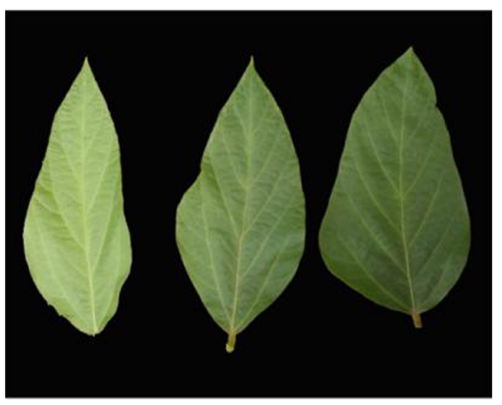

F

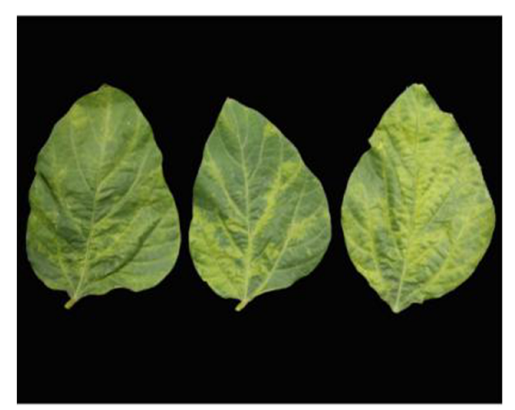

I

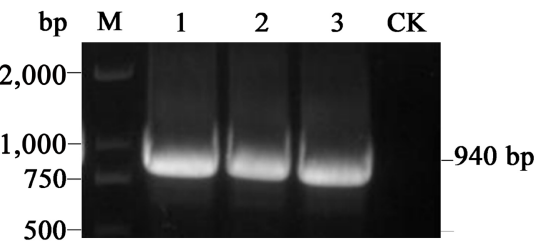

Fig. 5. Plants inoculated with the infectious SMV-SX clone all showed symptoms and reverse transcription polymerase chain reaction detection. (A) Normal Ailanthus altissima plant. (B) Normal soybean 1138-2 plant. (C) Normal soybean Kefeng No. 1 plant. (D) Susceptible A. altissima plant showing mosaic symptoms. (E) Susceptible soybean 1138-2 plant showing mosaic symptoms. (F) Susceptible soybean Kefeng No. 1 showing mosaic symptoms. (G) Amplification results from the SMV-CP primer in A. altissima. (H) Amplification results from the SMV-CP primer in soybean 1138-2. (I) Amplification results from SMV-CP primer in soybean of Kefeng No. 1. SMV, soybean mosaic virus; SMV-SX, SMV Shanxi isolate. M, DL 2000 DNA marker; lanes 1-3, inoculated plants; CK, non-inoculated plant.

directed mutations of infectious clones, it was possible to obtain attenuated strains, thus achieving cross-protection (Chiang et al., 2007).

However, studies have shown that there are special sequences in the Potyvirus that can cause varying degrees of toxicity to E. coli (Chikh Ali et al., 2011; Johansen and Lund, 2008). However, the specific mechanism underlying these effects has yet to be identified. This makes the construction of infectious clones of SMV more difficult. In the current study, Gibson assembly technology was used to rapidly construct an infectious SMV clone shuttle plasmid. This construction overcomes the time-consuming and laborious nature of the traditional method used to construct infectious clones, and also avoided the toxicity of SMV infectious clones to E. coli. To our knowledge, this study represents the first construction of a full-length infectious cDNA of SMV that is capable of infecting soybean and Altissima by using Gibson assembly technology. The agroinfectious clone described herein can therefore be useful for further studies of plant-virus interaction and the characterization of viral genes. Our findings also lay down the foundation for studying the mechanisms associated with cross-family SMV infection.

SMV only has a very narrow range of hosts, and generally only infects Leguminosae. Over recent years, our laboratory has found that SMV can infect $P$. ternata 
(Araceae) and A. atractylodes (Compositae), although the mechanism underlying cross-family infection remains unclear. Sequence comparison revealed that there was a significant difference between the P1 protein of a SMV$P$. ternata isolate and a SMV soybean isolate (data not published). Other researches have suggested that this nonconservative protein plays a key role in the successful adaptation of Potyviruses into a wide range of host species (Rohožkoá and Navrátil, 2011; Valli et al., 2007). At present, our laboratory is conducting further research on P1 protein to investigate its impact on cross-family SMV infection. Based on our previously constructed infectious clone of SMV-P. ternate isolate (Zhang et al., 2020) and this study constructed infectious clone of SMV soybean isolate, the molecular mechanism of SMV cross-family infection was to clarify by exchanging the P1 protein and other differential proteins.

\section{Conflicts of Interest}

No potential conflict of interest relevant to this article was reported.

\section{Acknowledgments}

This study was supported by National Natural Science Foundation of China (No. 31772130), China Agriculture Research System (Grant No. CARS-21) and Modern Agroindustry Technology Research System (No. 2020-05). Authors also thank to Dr Tuo Decai and Dr Niu Jingping for providing the vector pGreen-35S and soybean seeds. The authors would like to express their gratitude to EditSprings (https://www. editsprings.com/) for the expert linguistic services provided.

\section{Electronic Supplementary Material}

Supplementary materials are available at The Plant Pathology Journal website (http://www.ppjonline.org/).

\section{References}

Ahlquist, P., French, R., Janda, M. and Loesch-Fries, L. S. 1984. Multicomponent RNA plant virus infection derived from cloned viral cDNA. Proc. Natl. Acad. Sci. U. S. A. 81:70667070 .

Bedoya, L. C. and Daròs, J. A. 2010. Stability of tobacco etch virus infectious clones in plasmid vectors. Virus Res. 149:234240.

Boyer, J. C. and Haenni, A. L. 1994. Infectious transcripts and cDNA clones of RNA viruses. Virology 198:415-426.
Chapman, S., Kavanagh, T. and Baulcombe, D. 1992. Potato virus $\mathrm{X}$ as a vector for gene expression in plants. Plant J. 2:549557.

Chiang, C.-H., Lee, C.-Y., Wang, C.-H., Jan, F.-J., Lin, S.-S., Chen, T.-C., Raja, J. A. J. and Yeh, S.-D. 2007. Genetic analysis of an attenuated papaya ringspot virus strain applied for cross-protection. Eur. J. Plant Pathol. 118:333-348.

Chiang, C.-H. and Yeh, S.-D. 1997. Infectivity assays of in vitro and in vivo transcripts of papaya ringspot potyvirus. Bot. Bull. Acad. Sin. 38:153-163.

Chikh Ali, M., Said Omar, A. and Natsuaki, T. 2011. An infectious full-length cDNA clone of potato virus $\mathrm{Y}^{\mathrm{NTN}-\mathrm{NW}}$, a recently reported strain of PVY that causes potato tuber necrotic ringspot disease. Arch. Virol. 156:2039-2043.

Cui, L.-Y., Pang, X.-J., Qi, Y.-H., Wang, B.-X., Wang, D.-F. and Niu, Y.-B. 2018. Identification of the pathogens of Pinellia ternata virus by small RNA deep sequencing. Chin. J. Biochem. Mol. Biol. 34:1334-1341 (in Chinese).

Dolja, V. V., McBride, H. J. and Carrington, J. C. 1992. Tagging of plant potyvirus replication and movement by insertion of ß-glucuronidase into the viral polyprotein. Proc. Natl. Acad. Sci. U. S. A. 89:10208-10212.

Domier, L. L., Franklin, K. M., Hunt, A. G., Rhoads, R. E. and Shaw, J. G. 1989. Infectious in vitro transcripts from cloned cDNA of a potyvirus, tobacco vein mottling virus. Proc. Natl. Acad. Sci. U. S. A. 86:3509-3513.

Flasinski, S., Gunasinghe, U. B., Gonzales, R. A. and Cassidy, B. G. 1996. The cDNA sequence and infectious transcripts of peanut stripe virus. Gene 171: 299-300.

Flatken, S., Ungewickell, V., Menzel, W. and Maiss, E. 2008. Construction of an infectious full-length cDNA clone of potato virus M. Arch. Virol. 153:1385-1389.

Galiakparov, N., Tanne, E., Sela, I. and Gafny, R. 2003. Functional analysis of the grapevine virus A genome. Virology 306:4250.

Gal-On, A., Antignus, Y., Rosner, A. and Raccah, B. 1991. Infectious in vitro RNA transcripts derived from cloned cDNA of the cucurbit potyvirus, zucchini yellow mosaic virus. J. Gen. Virol. 72:2639-2643.

Hellens, R. P., Edwards, E. A., Leyland, N. R., Bean, S. and Mullineaux, P. M. 2000. pGreen: a versatile and flexible binary Ti vector for Agrobacterium-mediated plant transformation. Plant Mol. Biol. 42:819-832.

Jakab, G., Droz, E., Brigneti, G., Baulcombe, D. and Malnoë, P. 1997. Infectious in vivo and in vitro transcripts from a fulllength cDNA clone of PVY-N605, a Swiss necrotic isolate of potato virus Y. J. Gen. Virol. 78:3141-3145.

Johansen, I. E. and Lund, O. S. 2008. Insertion of introns: a strategy to facilitate assembly of infectious full length clones. Methods Mol. Biol. 451:535-544.

Kang, M., Seo, J.-K., Choi, H., Choi, H.-S. and Kim, K.-H. 2016. Establishment of a simple and rapid gene delivery system for cucurbits by using engineered of Zucchini yellow mosaic virus. Plant Pathol. J. 32:70-76. 
Kim, K.-S., Oh, H.-Y., Suranto, S., Nurhayati, E., Gough, K. H., Shukla, D. D. and Pallaghy, C. K. 2003. Infectivity of in vitro transcripts of Johnsongrass mosaic potyvirus full-length cDNA clones in maize and sorghum. Arch. Virol. 148:563574.

Kondo, T. and Fujita, T. 2012. Complete nucleotide sequence and construction of an infectious clone of Chinese yam necrotic mosaic virus suggest that macluraviruses have the smallest genome among members of the family Potyviridae. Arch. Virol. 157:2299-2307.

Kou, L., Zhao, H., Wang, D., Guo, S. and Niu, Y. 2017. Molecular identification of pathogens infecting Bupleurum chinese. Chin. J. Virol. 33:610-616 (in Chinese).

Krajacić, M., Ivancic-Jelecki, J., Forcic, D., Vrdoljak, A. and Skorić, D. 2007. Purification of plant viral and satellite double-stranded RNAs on DEAE monoliths. J. Chromatogr A. 1144:111-119.

Lee, M. Y., Song, Y. S. and Ryu, K. H. 2011. Development of infectious transcripts from full-length and GFP-tagged cDNA clones of pepper mottle virus and stable systemic expression of GFP in tobacco and pepper. Virus Res. 155:487-494.

Li, H., Dai, H.-Y., Zhang, Z.-H., Gao, X.-Y., Du, G.-D. and Zhang, X.-Y. 2007. Isolation and identification of virus dsRNA from strawberry plants. Agric. Sci. China 6:86-93.

Lin, S.-S., Hou, R. F. and Yeh, S.-D. 2002. Construction of in vitro and in vivo infectious transcripts of a Taiwan strain of zucchini yellow mosaic virus. Bot. Bull. Acad. Sin. 43:261269.

Liu, L. and Lomonossoff, G. 2002. Agroinfection as a rapid method for propagating cowpea mosaic virus-based constructs. J. Virol. Methods 105:343-348.

Naderpour, M. and Johansen, I. E. 2011. Visualization of resistance responses in Phaseolus vulgaris using reporter tagged clones of bean common mosaic virus. Virus Res. 159:1-8.

Nicolas, O., Dunnington, S. W., Gotow, L. F., Pirone, T. P. and Hellmann, G. M. 1997. Variations in the VPg protein allow a potyvirus to overcome va gene resistance in tobacco. Virology 237:452-459.

Niu, J. X., Liu, L. K., Zhu, J. and Zuo, W. M. 2003. Study on the RT-PCR detection system for pear vein yellow virus by using dsRNA as template. J. Fruit Sci. 20:143-145 (in Chinese).

Niu, Y., Pang, X., Wang, D., Guo, S. and Liu, Y. 2018. Deep sequencing analysis of a strain of pecan mosaic-associated virus infecting Atractylodes macrocephala Koidz. J. Plant Pathol. 100:249-255.

Puurand, U., Valkonen, J. P. T., Mäkinen, K., Rabenstein, F. and Saarma, M. 1996. Infectious in vitro transcripts from cloned cDNA of the potato A potyvirus. Virus Res. 40:135-140.

Rajamäki, M.-L. and Valkonen, J. P. T. 2009. Control of nuclear and nucleolar localization of nuclear inclusion protein a of picorna-like potato virus A in Nicotiana species. Plant Cell 21:2485-2502.

Rizzo, T. M. and Palukaitis, P. 1990. Construction of full-length cDNA clones of cucumber mosaic virus RNAs 1, 2 and 3: generation of infectious RNA transcripts. Mol. Gen. Genet. 222:249-256.

Rohozková, J. and Navrátil, M. 2011. P1 peptidase-a mysterious protein of family Potyviridae. J. Biosci. 36:189-200.

Sánchez, F., Martínez-Herrera, D., Aguilar, I. and Ponz, F. 1998. Infectivity of turnip mosaic potyvirus cDNA clones and transcripts on the systemic host Arabidopsis thaliana and local lesion hosts. Virus Res. 55:207-219.

Sastry, K. S. and Zitter, T. A. 2014. Plant virus and viroid diseases in the tropics. Vol. 2. Epidemiology and management. Springer, The Netherlands. 489 pp.

Seo, J.-K., Lee, H.-G. and Kim, K.-H. 2009. Systemic gene delivery into soybean by simple rub-inoculation with plasmid DNA of a soybean mosaic virus-based vector. Arch. Virol. 154:87-99.

Shentu, S. S. 2006. Detection of viruses infecting Pinellia ternata (Thunb.) Breit and phylogenetic study on soybean mosaic virus. M.S. thesis. Zhejiang University, Zhejiang, China (in Chinese).

Shi, B.-J., Ding, S.-W. and Symons, R. H. 1997. Plasmid vector for cloning infectious cDNAs from plant RNA viruses: high infectivity of cDNA clones of tomato aspermy cucumovirus. $J$. Gen. Virol. 78:1181-1185.

Shi, Y. H. 2007. Molecular characterization of potyviruses infecting aroid plants for medicinal use in China. Ph.D. thesis. Zhejiang University, Zhejiang, China (in Chinese).

Sparkes, I. A., Runions, J., Kearns, A. and Hawes, C. 2006. Rapid, transient expression of fluorescent fusion proteins in tobacco plants and generation of stably transformed plants. Nat. Protoc. 1:2019-2025.

Stephan, D. and Maiss, E. 2006. Biological properties of beet mild yellowing virus derived from a full-length cDNA clone. J. Gen. Virol. 87:445-449.

Stewart, L. R., Bouchard, R., Redinbaugh, M. G. and Meulia, T. 2012. Complete sequence and development of a full-length infectious clone of an Ohio isolate of maize dwarf mosaic virus (MDMV). Virus Res. 165:219-224.

Sun, H., ShenTu, S., Xue, F., Duns, G. and Chen, J. 2008. Molecular characterization and evolutionary analysis of soybean mosaic virus infecting Pinellia ternata in China. Virus Genes 36:177-190.

Tian, W. H. and Wang, J. Z. 1995. Applications dsRNA analysis to the detection of RNA viruses. J. Hebei Agric. Univ. 18:112117 (in Chinese).

Tuo, D., Fu, L., Shen, W., Li, X., Zhou, P. and Yan, P. 2017. Generation of stable infectious clones of plant viruses by using Rhizobium radiobacter for both cloning and inoculation. Virology 510:99-103.

Tzanetakis, I. E. and Martin, R. R. 2008. A new method for extraction of double-stranded RNA from plants. J. Virol. Methods 149:167-170.

Valli, A., López-Moya, J. J. and García, J. A. 2007. Recombination and gene duplication in the evolutionary diversification of P1 proteins in the family Potyviridae. J. Gen. Virol. 
88:1016-1028.

Wang, D.-F., Zhang, X.-M., Yang, F. and Niu, Y.-B. 2016. Identification and analysis of complete genomic sequence of Youcai mosaic virus Rehmannia glutinosa isolate in Shanxi. Acta Phytopathol. Sin. 46:598-604 (in Chinese).

Yan, P., Shen, W., Gao, X., Li, X., Zhou, P. and Duan, J. 2012. High-throughput construction of intron-containing hairpin RNA vectors for RNAi in plants. PLoS ONE 7:e38186.

Yang, F., Niu, E.-B., Wang, D.-F. and Niu, Y.-B. 2017. Sequence analysis of $\mathrm{cp}$ gene of Malva vein clearing virus Althaea rosea isolates in China. Acta Phytopathol. Sin. 47:458-462 (in Chinese).

Zhang, L., Wang, D., Pei, Y., Xian, S. and Niu, Y. 2020. Construction and characterization of an infectious clone of Soybean mosaic virus isolate from Pinellia ternata. Chin. J. Biotechnol. 36:949-958 (in Chinese).

Zheng, C.-M., Chang, R.-Z. and Qiu, L.-J. 2000. Progress on the disease of soybean mosaic virus. Acta Phytopathol. Sin. 30:97-105 (in Chinese).

Zhi, H. J. 2005. Evaluation, inheritance and utilization of resistance in infection and resistance in development to Soybean mosaic virus. Ph.D. thesis. Nanjing Agricultural University, Nanjing, China (in Chinese).

Zhou, X. P. and Li, D. B. 1995. Application of double-stranded RNA technology in the study of plant viruses. Biotechnology $1: 1-4$.

Zhou, X. and $\mathrm{Pu}$, Z. 1990. Natural infection of pisum sativum by soybean mosaic virus in Nanjing. J. Nanjing Agric. Univ. 13:53-56 (in Chinese).

Zhu, H. Q., Chen, J. P. and Yu, S. Q. 2006. Construction of an infectious cDNA clone of ribgrass mosaic virus Shanghai isolate and its modification to express an epitope of Mycobacterium tuberculosis. Arch. Virol. 151:1853-1861. 